\title{
Preparation and Characterization of Polyhydroxybutyrate/Polycaprolactone Nanocomposites
}

\author{
Cha Ping Liau, ${ }^{1}$ Mansor Bin Ahmad, ${ }^{1}$ Kamyar Shameli, ${ }^{1,2}$ Wan Md Zin Wan Yunus, \\ Nor Azowa Ibrahim, ${ }^{1}$ Norhazlin Zainuddin, ${ }^{1}$ and Yoon Yee Then ${ }^{1}$ \\ ${ }^{1}$ Department of Chemistry, Faculty of Science, Universiti Putra Malaysia, 43400 Serdang, Selangor, Malaysia \\ ${ }^{2}$ Nanotechnology and Advance Materials Department, Materials \& Energy Research Center, Alborz, Karaj 31787/316, Iran \\ ${ }^{3}$ Department of Chemistry, Centre for Defence Foundation Studies, National Defence University of Malaysia, \\ 57000 Kuala Lumpur, Federal Territory of Kuala Lumpur, Malaysia
}

Correspondence should be addressed to Mansor Bin Ahmad; mansorahmad@gmail.com and Kamyar Shameli; kamyarshameli@gmail.com

Received 31 August 2013; Accepted 19 November 2013; Published 29 January 2014

Academic Editors: X. Ke and J.-M. Yeh

Copyright @ 2014 Cha Ping Liau et al. This is an open access article distributed under the Creative Commons Attribution License, which permits unrestricted use, distribution, and reproduction in any medium, provided the original work is properly cited.

\begin{abstract}
Polyhydroxybutyrate (PHB)/polycaprolactone (PCL)/stearate $\mathrm{Mg}$-Al layered double hydroxide (LDH) nanocomposites were prepared via solution casting intercalation method. Coprecipitation method was used to prepare the anionic clay $\mathrm{Mg}$ - $\mathrm{Al} \mathrm{LDH}$ from nitrate salt solution. Modification of nitrate anions by stearate anions between the LDH layers via ion exchange reaction. FTIR spectra showed the presence of carboxylic acid $(\mathrm{COOH})$ group which indicates that stearate anions were successfully intercalated into the $\mathrm{Mg}-\mathrm{Al} \mathrm{LDH}$. The formation of nanocomposites only involves physical interaction as there are no new functional groups or new bonding formed. X-ray diffraction (XRD) and transmission electron microscopy (TEM) indicated that the mixtures of nanocomposites are intercalated and exfoliated types. XRD results showed increasing of basal spacing from 8.66 to $32.97 \AA$ in modified stearate $\mathrm{Mg}-\mathrm{Al} \mathrm{LDH}$, and TEM results revealed that the stearate $\mathrm{Mg}-\mathrm{Al} \mathrm{LDH}$ layers are homogeneously distributed in the PHB/PCL polymer blends matrix. Enhancement in 300\% elongation at break and 66\% tensile strength in the presence of 1.0 wt \% of the stearate Mg-Al LDH as compare with PHB/PCL blends. Scanning electron microscopy (SEM) proved that clay improves compatibility between polymer matrix and the best ratio $80 \mathrm{PHB} / 20 \mathrm{PCL} / 1$ stearate $\mathrm{Mg}-\mathrm{Al} \mathrm{LDH}$ surface is well dispersed and stretched before it breaks.
\end{abstract}

\section{Introduction}

In the last decades, the production and the use of plastics which are synthetically derived from petroleum with not readily biodegradable have been gradually increased. Meanwhile, the amounts of plastic waste disposal has increased particularly in packaging application. Plastic waste consists of high degree of contamination which requires high energy cost to recycle [1]. The persistence of plastics waste in the environment, dwindling petroleum resources, shortage of landfill space, and the concerns over emissions of poisonous gases during incineration have fuelled efforts to develop biodegradable polymers from renewable resources to reduce the environmental pollution [2]. The term "biodegradable" materials is used to describe those materials which can be degraded and disintegrate by the enzymatic action of living organisms such as bacteria, yeasts, and fungi and the ultimate end-products of the degradation process, these being carbon dioxide, water and biomass under aerobic conditions and hydrocarbons, and methane and biomass under anaerobic conditions [3].

Polyhydroxybutyrate (PHB) is natural thermoplastic polyester which is produced by bacterial fermentation [4] and degrades fully in the environment without forming any toxic products. It is biodegradable [5] (after few weeks in soil) and biocompatible, but some of the drawbacks such as brittleness, inherent rigidity, high production cost, and low melt stability limit its applications. A feasible strategy to reduce its brittle character and increase its physical properties such as flexibility and elongation at break is by blending with 
polycaprolactone (PCL) which is a synthetic thermoplastic polyester produced from ring opening polymerization of $\varepsilon$ caprolactone [6] and chemical synthesis of crude oil. PCL has excellent mechanical properties, is highly flexible, is biodegradable [7] (within 2 years in soil), is biocompatible, and has good water, oil, and solvent resistance. The disadvantages of PCL are low glass transition temperature $\left(T_{\mathrm{g}}\right)$ and low melting point leading to thermal instability. Polymer blends constitute a route to combine specific properties from different polymers via blending process that is relatively simple and less expensive compared to synthesis of new materials [8]. The purpose of blending is to achieve intermediate or even superior properties while preserving the major characteristics of the pure components [9]. Much of the attention to polymer/clay nanocomposites has been made to improve the flexibility, compatibility, and mechanical properties of polymer blends with small filler concentration $[1,3]$. The final properties of nanocomposites with the filled of nanofiller depended on the filler dispersion and interaction at the polymer-filler interface [9].

Inorganic-organic nanocomposite materials with functional organic compounds immobilized into a layered inorganic matrix have potential to offer scientific and technological advantages, since the organized two-dimensional arrays of organic species between the interlayers can result in novel functions that are different to the typical functions of the individual organic species [10-20].

Layered double hydroxides (LDHs) are anionic clays with the general formula $\left[\mathrm{M}(\mathrm{II})_{1-X} \mathrm{M}(\mathrm{III})_{X}(\mathrm{OH})_{2}\right]^{X+}\left[\mathrm{A}_{X / n^{n-}}\right.$. $\left.m \mathrm{H}_{2} \mathrm{O}\right]^{X-}$ where $\mathrm{M}(\mathrm{II})$ and $\mathrm{M}(\mathrm{III})$ are divalent and trivalent cations, respectively, and $\mathrm{A}^{n-}$ is an exchangeable anion which is intercalated into interlayers to achieve charge neutrality [21]. Meanwhile, LDHs are host guest materials consisting of positively charged metal hydroxide sheets which remain stacked in $z$-direction with intercalated anions and water molecules [22]. This characteristic makes LDH materials suitable for polymer nanocomposites synthesis is the exchangeable nature of the interlayer anions by suitable oligomeric or polymeric anion [23]. Additionally, it is an advanced additive with the advantages of being environmentally friendly, economic, naturally abundant [24, 25], nontoxic, and room temperature prepared [26]. Naturally, LDHs are of hydrophilic character; in order to prepare high-performance nanocomposites, anion exchange process involves incorporating with long chain organic surfactant anion intercalation to reduce its hydrophilicity $[27,28]$. The presence of hydrophobic intercalated anion improves the clay compatibility with being homogeneously dispersed within hydrophobic polymer matrices by strong interfacial adhesion and facilitates penetration of the polymer chains into interlayer spaces [29]. The aim of modification is to enlarge the interlayer distance and make LDH more hydrophobic [30]. The unusual packing of the organic anions in LDH gallery may facilitate their easier incorporation into polymers, leading to better nanocomposites formation [31]. The potential application outcomes could be the development of flame retardant composites, while improving the mechanical reinforcement and thermal stability due to the nanoscale filler dispersion [32] and strength of the polymer/filler interfaces [33].

Costa et al. [34] reported the preparation of intercalation of $\mathrm{Mg}-\mathrm{Al} \mathrm{LDH}$ by anionic surfactants revealing increment in interlayer distance of modified $\mathrm{Mg}-\mathrm{Al} \mathrm{LDH}$ depending on the length of the surfactant anions. Furthermore, Sanchez-Garcia et al. [35] carried out solution cast composites preparation due to the fact that the melt instability of PHB will direct melt compounding. Besides, they proved that addition of PCL component led to a finer dispersion of the clay with intercalated morphologies and exhibited improved thermal stability.

Recently, lots of researchers were focused on polymer blends and polymer nanocomposites by using biodegradable polymer to improve their use in application and to reduce the environmental pollution. Different biodegradable polymers and clay were used in this research work; the preparation and characterization of PHB/PCL nanocomposites have been described. It is worthwhile to investigate the effects of filler loading on the fracture toughness and the properties of composite materials. Significant improvements in morphology and mechanical properties were observed after the additional modified clay was incorporated into the PHB/PCL blend. Lee et al. [36] proved that the strong hydrogen bonding interaction between biodegradable aliphatic polyester and organoclay will lead to higher degree of intercalation and higher tensile properties caused by formation of nanocomposites with better dispersion.

\section{Experimental Details}

2.1. Materials. A bacterial crystalline thermoplastic polyhydroxybutyrate powder form was purchased from SigmaAldrich Chemic GmbH Company, Germany. Polycaprolactone (CAPA 650) with number-average molecular weight of 50,000 was supplied by Solvay Caprolactone (England). Magnesium nitrate hexahydrate and aluminium nitrate nonahydrate were supplied by HmbG chemicals (Hamburg, Germany). Sodium hydroxide pellets were obtained from Merck (Darmstadt, Germany). Sodium stearate was purchased from R\&M chemicals (Essex, UK).

2.2. Synthesis of $M g-A l L D H$. The Mg-Al LDH was prepared via coprecipitation method. $\mathrm{NaOH} 1 \mathrm{M}$ solution was added drop by drop into a $250 \mathrm{~mL}$ solution of $19.22 \mathrm{~g} \mathrm{Mg}\left(\mathrm{NO}_{3}\right)_{2}$. $6 \mathrm{H}_{2} \mathrm{O}(0.2 \mathrm{M})$ and $9.38 \mathrm{~g} \mathrm{Al}\left(\mathrm{NO}_{3}\right)_{3} \cdot 9 \mathrm{H}_{2} \mathrm{O}(0.067 \mathrm{M})$ (with the mole ratio of $3: 1$, resp.) until $\mathrm{pH} 9$ was acquired. It was carried out under vigorous stirring and constant flow of nitrogen $\mathrm{N}_{2}$ (g) to exclude carbon dioxide. The resulting suspension was shaken and heated at $70^{\circ} \mathrm{C}$ in water bath shaker at $100 \mathrm{rpm}$ of speed for about 16 hours. The slurry was filtered, washed methodically with distilled water, and dried in oven at $60^{\circ} \mathrm{C}$ for 24 hours to obtain the Mg-Al LDH [21].

2.3. Preparation of Stearate $\mathrm{Mg}-\mathrm{Al} \mathrm{LDH}$. Preparation of stearate- $\mathrm{Mg}_{3} \mathrm{Al} \mathrm{LDH}$ via replacement of nitrate ions in the $\mathrm{LDH}$ layers with stearate ions from sodium stearate. One gram of the dry powder Mg-Al LDH was mixed with 1.8388 
gram of sodium stearate and then dissolved in one liter of distilled water. The mixture was stirred for 24 hours and aged at $70^{\circ} \mathrm{C}$ of water bath to ensure complete reaction. Then, the white precipitate or slurry was filtered and washed with distilled water twice prior to drying at $60^{\circ} \mathrm{C}$. The dried sample was ground and sieved into particles size of less than 100 micrometer.

2.4. Preparation of PHB/PCL Blends. PHB/PCL blends were prepared by solution casting method with different PCL contents (10, 20,30,40, and 50\%). PHB and PCL were weighed, dissolved in $100 \mathrm{~mL}$ chloroform, and stirred for one hour, respectively. The two solutions were mixed and stirred for another 1 hour to obtain the homogeneous mixture solution. Besides, the mixture solutions were casted in a glass Petri dish and dried in the solvent atmosphere to obtain sample films.

\subsection{Preparation of $\mathrm{PHB} / \mathrm{PCL} /$ Stearate $\mathrm{Mg}$ - $\mathrm{Al} \mathrm{LDH}$ Nanocom-} posites. From the characterization results of $\mathrm{PHB} / \mathrm{PCL}$ blends, the optimum ratio of the blend was fixed at $80: 20$. The nanocomposites of $\mathrm{PHB} / \mathrm{PCL}$ blend with different amounts of stearate $\mathrm{Mg}-\mathrm{Al} \mathrm{LDH}(0.25,0.5,1,1.5$, and $2 \%)$ were carried out by solution casting process. PHB, PCL, and stearate Mg$\mathrm{Al} \mathrm{LDH}$ were dissolved and stirred in $100 \mathrm{~mL}$ chloroform for one hour, respectively. Then the three solutions were mixed together and stirred for another one hour. Solidification took place to evaporate excess amount of chloroform for 15 minutes. The mixture was poured on Petri dish and left in fume cupboard for solvent evaporation to obtain dried films.

2.6. Fourier Transform Infrared (FTIR) Spectroscopy. The functional groups, types of bonding, and identified components in the samples were determined by a Perkin Elmer Spectrum 1000 Series Spectrophotometer equipped with attenuated total reflectance (ATR). The infrared spectra of the samples were recorded in the range of frequency of $400-$ $4000 \mathrm{~cm}^{-1}$.

2.7. X-Ray Diffraction (XRD). A Shimadzu XRD 6000 Diffractometer with nickel filtered $\mathrm{Cu}-\mathrm{K}_{\alpha}(\lambda=0.1542 \mathrm{~nm})$ beam operated at $30 \mathrm{kV}$ and $30 \mathrm{~mA}$ was used to determine the interlayer $d$-spacing of the clay layer in the original $\mathrm{Mg}-\mathrm{Al} \mathrm{LDH}$, modified stearate $\mathrm{Mg}-\mathrm{Al} \mathrm{LDH}$, blends, and nanocomposites using Bragg's equation $n \lambda=2 d \sin \theta$. Data were recorded in $2 \theta$ range of $2^{\circ}-30^{\circ}$ using the scan rate of $2^{\circ} / \mathrm{min}$.

2.8. Tensile Properties Measurement. Tensile test was carried out by a Universal Testing Machine, Instron 4302, according to ASTM D638-5. A crosshead speed of $5 \mathrm{~mm} / \mathrm{min}$ and a load cell of $1 \mathrm{kN}$ were used and the tests were performed at $25^{\circ} \mathrm{C}$. The samples films were cut into dumbbell shape using dumbbell cutter (Die BS 6476) and thickness of the samples was measured using a thickness gauge. The results were expressed in terms of tensile strength, tensile modulus, and elongation at break. Seven specimens were

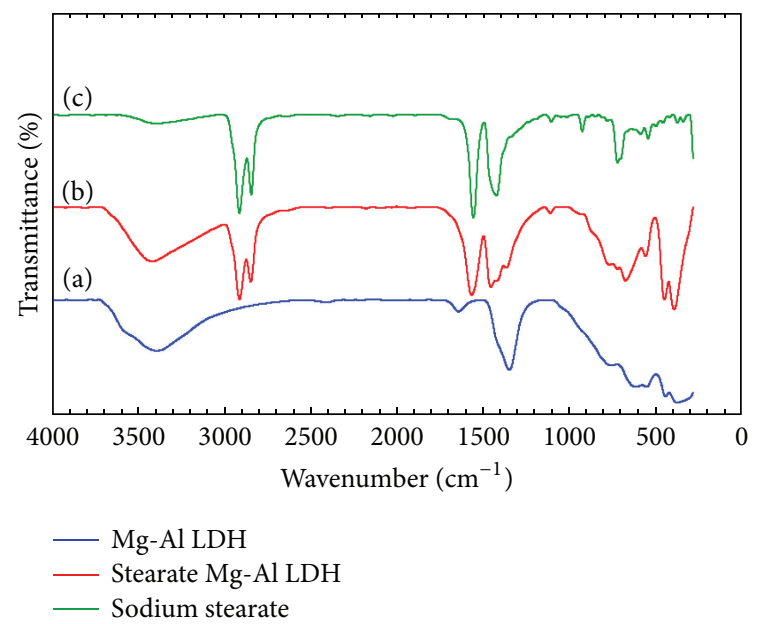

FIGURE 1: FTIR spectra for (a) pristine Mg-Al LDH, (b) stearate Mg$\mathrm{Al} \mathrm{LDH}$, and (c) sodium stearate.

tested and the averages of five best measurements were reported.

2.9. Scanning Electron Microscopy (SEM). The scanning electron micrographs of tensile fracture surface of the samples were recorded by a JSM-6400 scanning microscope which is a state-of-the-art high resolution scanning electron microscope with a modern digital image processing system. This SEM Joel operated at $20 \mathrm{kV}$ to investigate the surface morphology of samples. The samples were coated with gold by a Bio-Rad coating system before viewing. The scanning electron micrographs were recorded at the magnification of 2000x.

2.10. Transmission Electron Microscopy (TEM). The transmission electron micrographs of the thin layer of the nanocomposites were recorded by a LEO 912 A Benergy filter transmission electron microscope with an acceleration voltage of $100 \mathrm{keV}$. The thin layer of samples was prepared using a Reichert Jung Ultracut E microtome equipped with cryosectioning unit. The samples were sliced into thin layer of about $90 \mathrm{~nm}$ by a diamond knife cooled at $-120^{\circ} \mathrm{C}$ with liquefied nitrogen.

\section{Results and Discussion}

3.1. Characterization of $M g-A l L D H$ and Stearate $M g-A l L D H$. Figure 1 shows the FTIR spectra of $\mathrm{Mg}-\mathrm{Al} \mathrm{LDH}$ and stearate $\mathrm{Mg}-\mathrm{Al} \mathrm{LDH}$ which have broad adsorption bands at around $3399.51 \mathrm{~cm}^{-1}$ and $3420.04 \mathrm{~cm}^{-1}$, respectively. This is due to the $\mathrm{O}-\mathrm{H}$ group stretching of both hydroxide layers and interlayer water molecules. Although the samples were calcined for longer time, the absorption bands persist which might be caused by strong bonded internal - $\mathrm{OH}$ group. An absorption band observed at $1600-1650 \mathrm{~cm}^{-1}$ is attributed to the $\mathrm{H}-\mathrm{OH}$ bending vibration of the interlayer water. Absorption bands at below $800 \mathrm{~cm}^{-1}$ region are the lattice vibration bands of J-O 


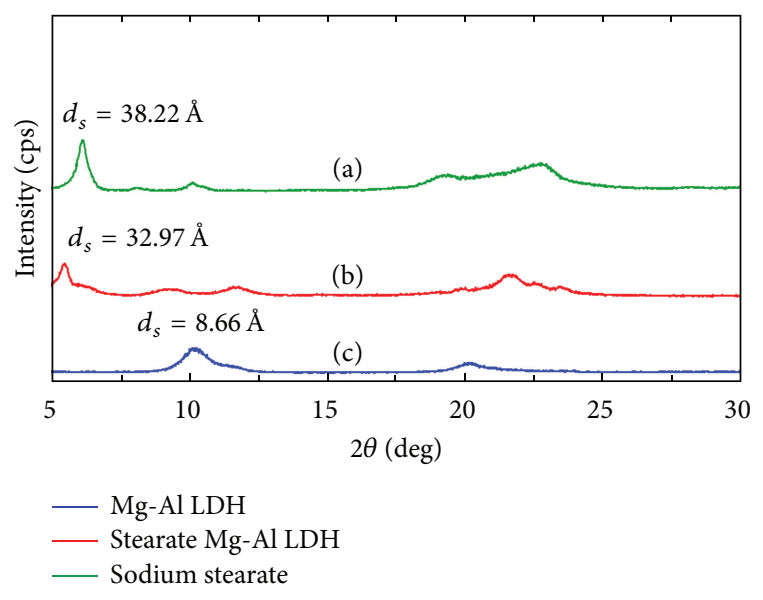

FIGURE 2: XRD patterns of (a) pristine $\mathrm{Mg}-\mathrm{Al} \mathrm{LDH}$, (b) stearate $\mathrm{Mg}$ $\mathrm{Al} \mathrm{LDH}$, and (c) sodium stearate.

and $\mathrm{O}-\mathrm{J}-\mathrm{O}(\mathrm{J}=\mathrm{Mg}$ or $\mathrm{Al})$. An intense band which is shown in $\mathrm{Mg}-\mathrm{Al} \mathrm{LDH}$ at $1348.42 \mathrm{~cm}^{-1}$ is an asymmetric stretching vibration of nitrate anions [37]. Spectra 1(b) and 1(c) proved that the $\mathrm{C}-\mathrm{H}$ stretching vibration due to the presence of the $-\mathrm{CH}_{3}$ and $-\mathrm{CH}_{2}$ xgroups of long chain stearate anions [38] is observed at $2800-3000 \mathrm{~cm}^{-1}$ which has no peak at the spectrum 1(a). Meanwhile, two strong absorption peaks that located at $1566.73 \mathrm{~cm}^{-1}$ and $1455.02 \mathrm{~cm}^{-1}$ are assigned to carboxylate asymmetric and symmetric stretching [39]. As a conclusion, the stearate anions were successfully replacing the nitrate anions which were intercalated between the layers.

Figure 2 shows the XRD patterns of Mg-Al LDH, stearate $\mathrm{Mg}-\mathrm{Al} \mathrm{LDH}$, and sodium stearate in the determination range of $2 \theta$ from 2 to $30^{\circ}$. Both $\mathrm{Mg}-\mathrm{Al} \mathrm{LDH}$ and stearate $\mathrm{Mg}-\mathrm{Al} \mathrm{LDH}$ are crystalline solids with well-defined layered structure. From the determination of basal spacing by Bragg's equation, $n \lambda=2 d \sin \theta$, where $n$ is equal to 1 for $<003>$ peak, $\lambda$ is the wavelength of $\mathrm{Cu}-\mathrm{K}_{\alpha}$ radiation, and $\theta$ is the half of the scattering angle. The sodium stearate diffractogram shows a sharp peak at $2 \theta$ of $2.22^{\circ}$ corresponding to the $d$-spacing of $39.80 \AA$ which proved that the organic modifier increased clay interlayer distance. The chemical modification process indicates enhancement of $d$-spacing from $8.66 \AA$ in $\mathrm{Mg}$-Al $\mathrm{LDH}$ (corresponding $2 \theta$ value is $10.22^{\circ}$ ) to $32.97 \AA$ in stearate $\mathrm{Mg}-\mathrm{Al} \mathrm{LDH}$ (corresponding $2 \theta$ value is $2.68^{\circ}$ ). This increment means that the stearate anions are successfully intercalated into the $\mathrm{Mg}-\mathrm{Al} \mathrm{LDH}$ interlayer and replace the nitrate anion via the anion exchange method [40]. In other words, long tail of hydrophobic chain of stearate anions will increase the $d$-spacing by radiating away the hydrophobic side of stearate anion from surface and hydrophilic side resides in the interlayer of LDH [34].

3.2. Characterization of $P H B / P C L /$ Stearate $M g-A l ~ L D H ~$ Nanocomposites. Stearate Mg-Al LDH was produced by the anion exchange reaction between $\mathrm{NO}_{3}{ }^{-}$anion in the interlayer of $\mathrm{Mg}-\mathrm{Al} \mathrm{LDH}$ and stearate anion $\mathrm{H}_{3} \mathrm{C}\left(\mathrm{CH}_{2}\right)_{16} \mathrm{COO}^{-}$ from organic modifier sodium stearate. The replacement of

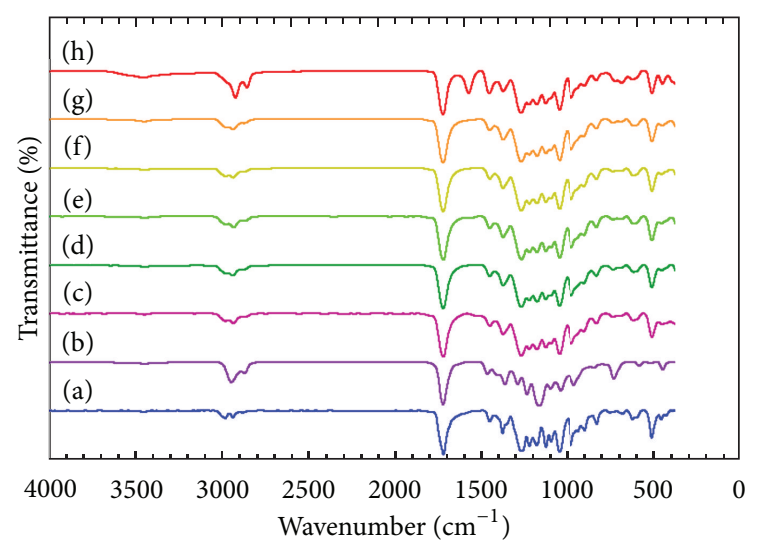

FIGURE 3: FTIR spectra of (a) pure PHB, (b) pure PCL, and (c) 80PHB/20PCL blend and PHB/PCL/stearate Mg-Al LDH nanocomposite with (d) 0.25 , (e) 0.5 , (f) 1 , (g) 1.5 , and (h) $2 \mathrm{wt} \%$ stearate $\mathrm{Mg}-\mathrm{Al}$ LDH content.

anion position $\mathrm{NO}_{3}{ }^{-}$with $\mathrm{H}_{3} \mathrm{C}\left(\mathrm{CH}_{2}\right)_{16} \mathrm{COO}^{-}$anion enlarges the interlayer $d$-spacing and reduces hydrophilic surface of Mg-Al LDH. Clay with hydrophobic surface leads to easy intercalation of polymer chain within the clay layer due to the fact that the same polar will increase the dispersion. The stearate $\mathrm{Mg}-\mathrm{Al} \mathrm{LDH}$ produced was the solution casting with PHB/PCL blend with the weight ratio of $80: 20$ to formed $\mathrm{PHB} / \mathrm{PCL} /$ stearate $\mathrm{Mg}$-Al $\mathrm{LDH}$ nanocomposites. The previous investigation shows that $80 \mathrm{PHB} / 20 \mathrm{PCL}$ blend had the higher tensile strength and elongation at break, so this weight ratio was chosen as our optimum blend.

Figure 3 shows the FTIR spectra of pure PHB, pure PCL, 80PHB/20PCL blend, and PHB/PCL/stearate Mg-Al LDH nanocomposites with different stearate $\mathrm{Mg}$-Al LDH contents. The spectra 3(a) and 3(b) have the almost same functional group and peak of spectrum where absorption band is at $3442.37 \mathrm{~cm}^{-1}$ and $3444.95 \mathrm{~cm}^{-1}$, respectively, corresponding to broad O-H stretching. C-H group located at 2933.87 and 2978.11 reflecting lipid nature of PHB such as symmetricasymmetric stretching band of methyl-methylene. Meanwhile, the peaks which appeared at $2942.37 \mathrm{~cm}^{-1}$ and $2867.18 \mathrm{~cm}^{-1}$ are due to the $\mathrm{C}-\mathrm{H}$ stretching in spectrum 3(b). Beside, a strongest ester carbonyl absorption band, $\mathrm{C}=\mathrm{O}$ stretching vibration located at $1719.54 \mathrm{~cm}^{-1}$ and $1722.17 \mathrm{~cm}^{-1}$ respectively. An asymmetrical $\mathrm{C}-\mathrm{H}$ bending vibration in $\mathrm{CH}_{3}$ group showed an absorption band at $1453.33 \mathrm{~cm}^{-1}$ and $1466.56 \mathrm{~cm}^{-1}$, respectively. $\mathrm{C}-\mathrm{O}-\mathrm{H}$ bond shows a peak at $1378.95 \mathrm{~cm}^{-1}$ and $1365.30 \mathrm{~cm}^{-1}$ respectively. Additionally, FTIR spectra $3(\mathrm{a})$ and $3(\mathrm{~b})$ present at $1181.48 \mathrm{~cm}^{-1}$ and $1167.31 \mathrm{~cm}^{-1}$ are attributed to $\mathrm{C}-\mathrm{O}$ stretching. The spectra of $\mathrm{PHB} / \mathrm{PCL}$ blend 3(c) and $\mathrm{PHB} / \mathrm{PCL} /$ stearate $\mathrm{Mg}-\mathrm{Al} \mathrm{LDH}$ nanocomposites $3(\mathrm{~d}), 3(\mathrm{e}), 3(\mathrm{f}), 3(\mathrm{~g})$, and $3(\mathrm{~h})$ are consistent with the combination of pure PHB and pure PCL spectra. There is no major peak shifting or formation of new peak in the blend and nanocomposites spectra caused by no strong interaction and bonding between PHB, PCL and stearate Mg$\mathrm{Al} \mathrm{LDH} \mathrm{[29].}$ 


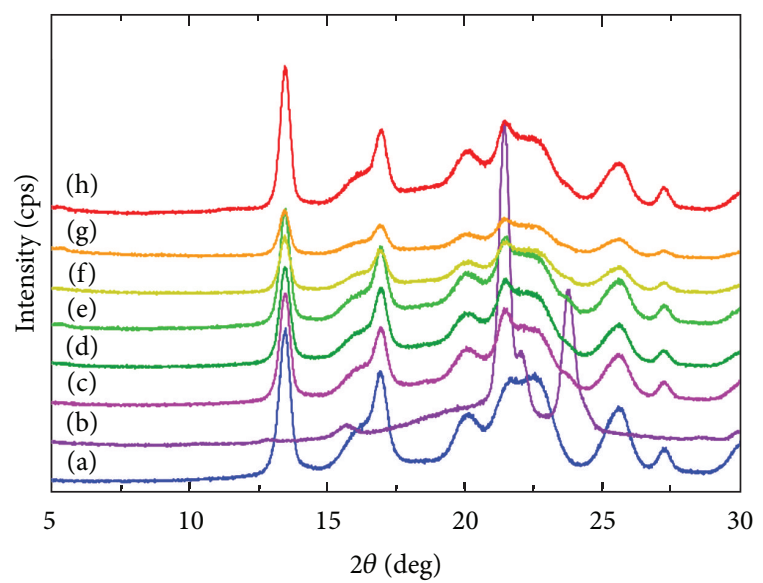

Figure 4: XRD patterns of (a) pure PHB, (b) pure PCL, and (c) 80PHB/20PCL and PHB/PCL/stearate Mg-Al LDH nanocomposites with (d) 0.25 , (e) 0.5 , (f) 1 , (g) 1.5 , and (h) 2 wt\% stearate Mg-Al LDH content.

Figure 4 shows the XRD patterns of pure $\mathrm{PHB}$, pure PCL, optimum ratio of PHB/PCL blend, and PHB/PCL/LDH nanocomposites of various amounts of the stearate $\mathrm{Mg}-\mathrm{Al}$ $\mathrm{LDH}$ contents. The absence of the main diffraction peak at around $2.00^{\circ}$ for very low concentrations such as 0.25 and $0.5 \mathrm{wt} \%$ stearate $\mathrm{Mg}-\mathrm{Al} \mathrm{LDH}$ nanocomposites shows that the LDH layers are completely exfoliated and randomly dispersed in the PHB/PCL polymer blend matrix [21]. For the nanocomposites that contain $1,1.5$, and $2 \mathrm{wt} \%$ stearate $\mathrm{Mg}$ $\mathrm{Al} \mathrm{LDH}$ nanocomposite there is a very small peak at $2 \theta$ of $2.195^{\circ}, 2.275^{\circ}$, and $2.325^{\circ}$ with $40.20 \AA, 38.78 \AA$, and $38.00 \AA$ interlayer spacing, respectively. This increment of $d$-spacing indicates that polymer chains are intercalated into the clay layers to form intercalated type nanocomposites.

The formation of nanocomposites can be directly observed by TEM. The transmission electron micrographs of optimum $80 \mathrm{PHB} / 20 \mathrm{PCL}$ polymer blend and $80 \mathrm{PHB} / 20 \mathrm{PCL} /$ 1stearate $\mathrm{Mg}-\mathrm{Al} \mathrm{LDH}$ nanocomposites are shown in Figure 5. In Figure 5(a), both of the polymers are organic polymers which dispersed well together so that the surfaces look smooth. After the addition of inorganic stearate Mg-Al LDH clay, the dark lines in Figure 5(b) represent the LDH layers in the PHB/PCL polymer matrix. At low clay content $1 \mathrm{wt} \%$ stearate $\mathrm{Mg}-\mathrm{Al} \mathrm{LDH}$ ), clay is well dispersed in $\mathrm{PHB} / \mathrm{PCL}$ matrix which also indicated a mixture of intercalated and exfoliated type nanocomposites.

Figures 6,7 , and 8 show the tensile strength, modulus, and elongation at break of $\mathrm{PHB} / \mathrm{PCL} /$ stearate $\mathrm{Mg}$-Al LDH nanocomposites with effect of different stearate $\mathrm{Mg}$-Al LDH contents. The tensile strength of neat PHB is $23.00 \mathrm{MPa}$ and decreases to 17.02 MPa upon the addition of 20PCL. However, addition of $1 \mathrm{wt} \%$ of stearate $\mathrm{Mg}-\mathrm{Al} \mathrm{LDH}$ into $80 \mathrm{PHB} / 20 \mathrm{PCL}$ blend increases the tensile strength to $28.23 \mathrm{MPa}$ or an enhancement of $66 \%$ compared to the unfilled clay PHB/PCL blends. Tensile strength depends on the interaction between filler and polymer matrix; this result indicates that incorporating of stearate $\mathrm{Mg}-\mathrm{Al} \mathrm{LDH}$ increases interfacial adhesion

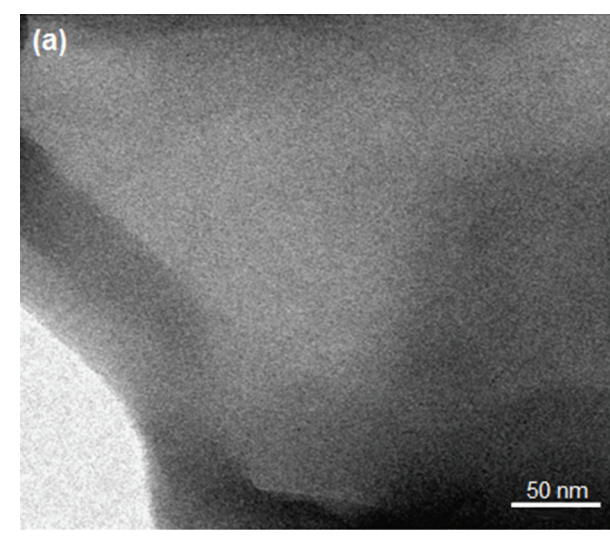

(a)

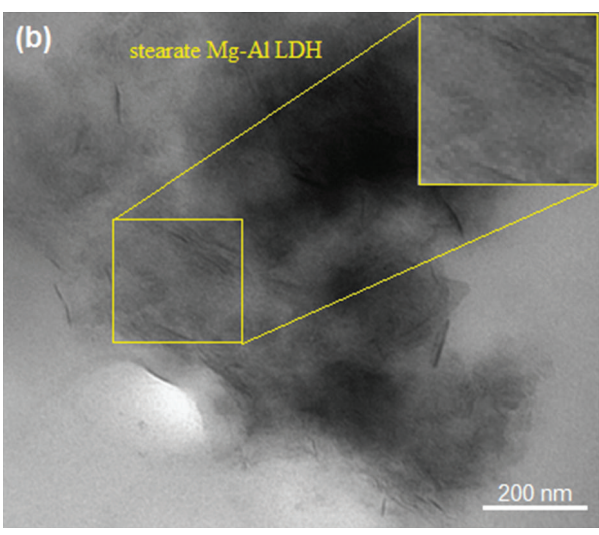

(b)

FIGURE 5: Transmission electron micrographs of (a) 80PHB/20PCL blend and (b) 80PHB/20PCL/1 wt\% stearate Mg-Al LDH nanocomposites.

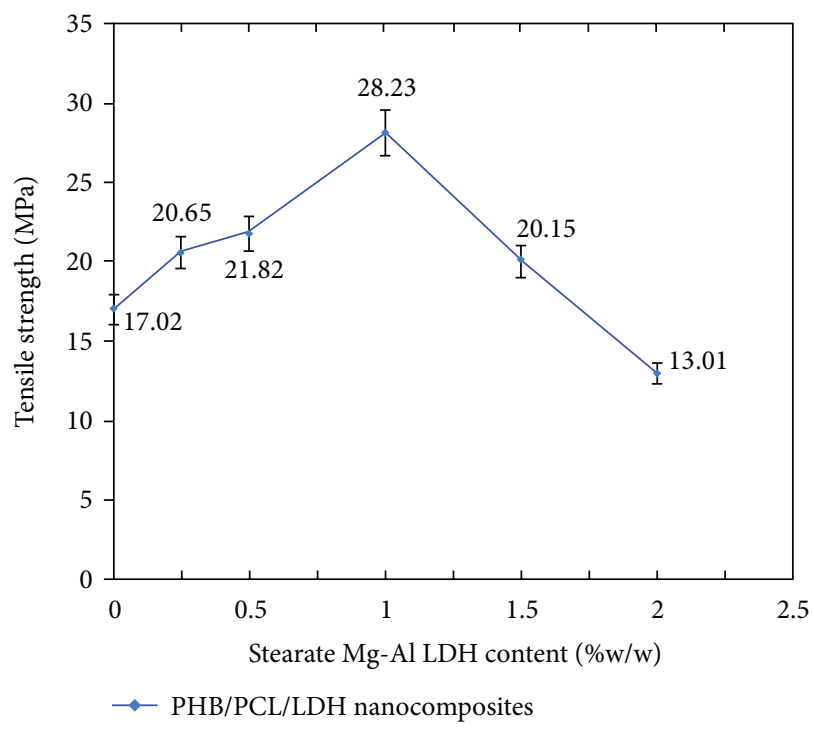

FIGURE 6: Tensile strength of PHB/PCL/stearate Mg-Al LDH nanocomposites with $0.25,0.5,1,1.5$, and $2 \mathrm{wt} \%$ stearate $\mathrm{Mg}$-Al LDH content. 


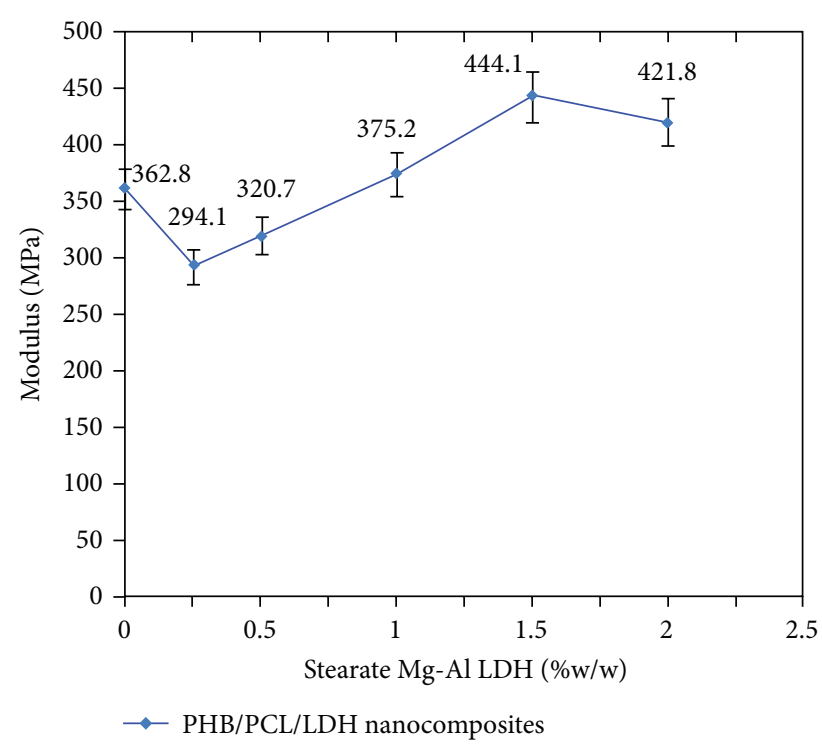

FIGURE 7: Modulus of PHB/PCL/stearate Mg-Al LDH nanocomposites with $0.25,0.5,1,1.5$, and $2 \mathrm{wt} \%$ stearate $\mathrm{Mg}-\mathrm{Al} \mathrm{LDH}$ content.

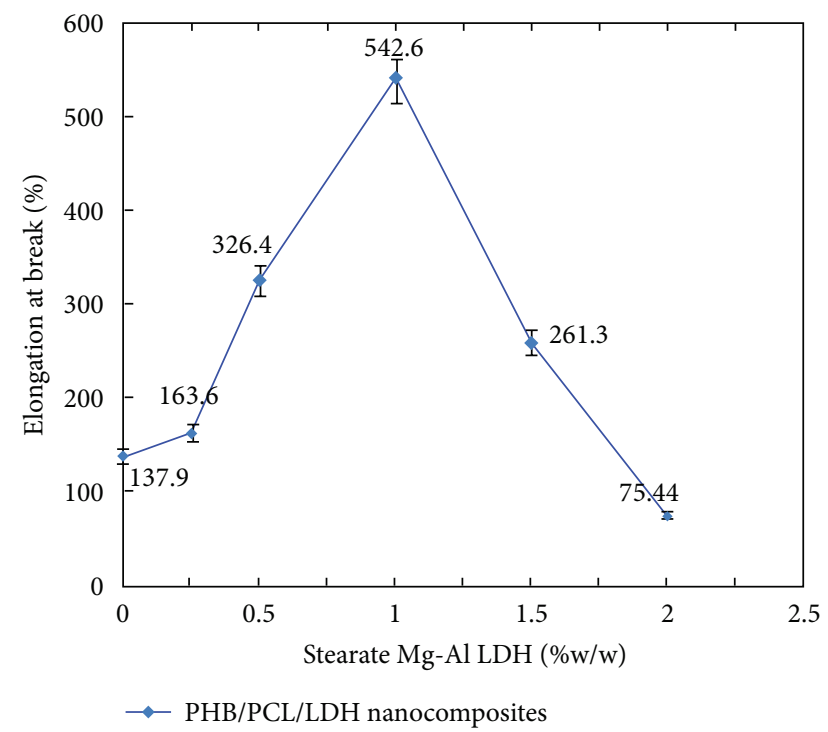

FIgURE 8: Elongation at break of PHB/PCL/stearate Mg-Al LDH nanocomposites with $0.25,0.5,1,1.5$, and $2 \mathrm{wt} \%$ stearate $\mathrm{Mg}-\mathrm{Al} \mathrm{LDH}$ content.

which may play an important role in causing compatibilization at a molecular level [41]. The compatibility of clay improves the stress transfer within nanocomposites leading to increased tensile strength. Further addition of high filler content probably favours the formation of inorganic clusters or agglomerates and therefore reduces the tensile strength. The tensile modulus of $\mathrm{PHB} / \mathrm{PCL} /$ stearate $\mathrm{Mg}-\mathrm{Al} \mathrm{LDH}$ nanocomposites increases with the increase of stearate $\mathrm{Mg}-\mathrm{Al}$ LDH content. This increment is probably caused by restriction of the polymer chains from the interaction with the clay surface [42] which make samples stiff and easy to break with low value of elongation at break. Meanwhile, higher modulus is attributed to the good dispersion of nanosize clay primary particles that restrict the mobility of polymer chain under loading and good interfacial adhesion between the clay layers [43].

Nanocomposites with $1 \mathrm{wt} \%$ stearate $\mathrm{Mg}$-Al LDH produced higher improvement in elongation at break which is $300 \%$ higher as compared with that of $80 \mathrm{PHB} / 20 \mathrm{PCL}$ blend. Stearate anions are considered as plasticizer since their long hydrocarbon segments improve the flexibility of polymer matrix [44]. This is observed in the presence of long chain hydrocarbon parts of stearate anions which are intercalated into the LDH layers with increment flexibility and elongation at break of nanocomposites. However, the graph displayed similar trend to tensile strength; further addition of stearate Mg-Al LDH decreases the elongation at break due to extended agglomerates which makes the nanocomposites more brittle $[45,46]$.

Figure 9 shows SEM micrographs obtained from the tensile fracture surfaces of PHB/PCL blend and its nanocomposites containing $0.25,0.5,1,1.5$, and $2 \mathrm{wt} \%$ of stearate $\mathrm{Mg}-\mathrm{Al} \mathrm{LDH}$. Figure 9(a) shows the fractured surface of optimum PHB/PCL blend with rough surface which reduces the rigidity of the samples. Figures $9(\mathrm{~b})-9(\mathrm{e})$ show rough and well stretched surface before it breaks, indicating that the presence of the stearate $\mathrm{Mg}-\mathrm{Al} \mathrm{LDH}$ improves the compatibility and flexibility in nanocomposites [29]. This reveals that stearate $\mathrm{Mg}-\mathrm{Al} \mathrm{LDH}$ is a good compatibilizer that enhances the mixing and interaction between the components in the nanocomposites. Additionally, this could be the reason why nanocomposites exhibit higher tensile strength and elongation at break compared to unfilled additive blends.

\section{Conclusion}

Modification of stearate $\mathrm{Mg}$-Al LDH was successfully prepared by coprecipitation and ion exchange reaction. Besides, $\mathrm{PHB} / \mathrm{PCL} /$ stearate $\mathrm{Mg}-\mathrm{Al} \mathrm{LDH}$ nanocomposites were prepared via solution casting method by using chloroform as organic solvent. XRD analysis reveals that low filler concentration produced exfoliated nanocomposites. The presence of $1 \mathrm{wt} \%$ of stearate $\mathrm{Mg}-\mathrm{Al} \mathrm{LDH}$ content shows that higher interlayer spacing and intercalated nanocomposites were produced by addition of high filler content. Moreover, there is no major peak shifting and no formation of new peak in FTIR spectrum indicated no strong interaction among PHB, $\mathrm{PCL}$, and stearate $\mathrm{Mg}-\mathrm{Al} \mathrm{LDH}$. Mechanical analyses showed that an $80 \mathrm{PHB} / 20 \mathrm{PCL} / 1$ stearate $\mathrm{Mg}-\mathrm{Al} \mathrm{LDH}$ nanocomposite was drastically enhanced by about $66 \%$ and $300 \%$ for its tensile strength and elongation at break. These improvements have been exhibited by SEM where the incorporation of stearate $\mathrm{Mg}-\mathrm{Al} \mathrm{LDH}$ clay gradually increases the flexibility and compatibility of nanocomposites.

\section{Conflict of Interests}

The authors declare that there is no conflict of interests regarding the publication of this paper. 

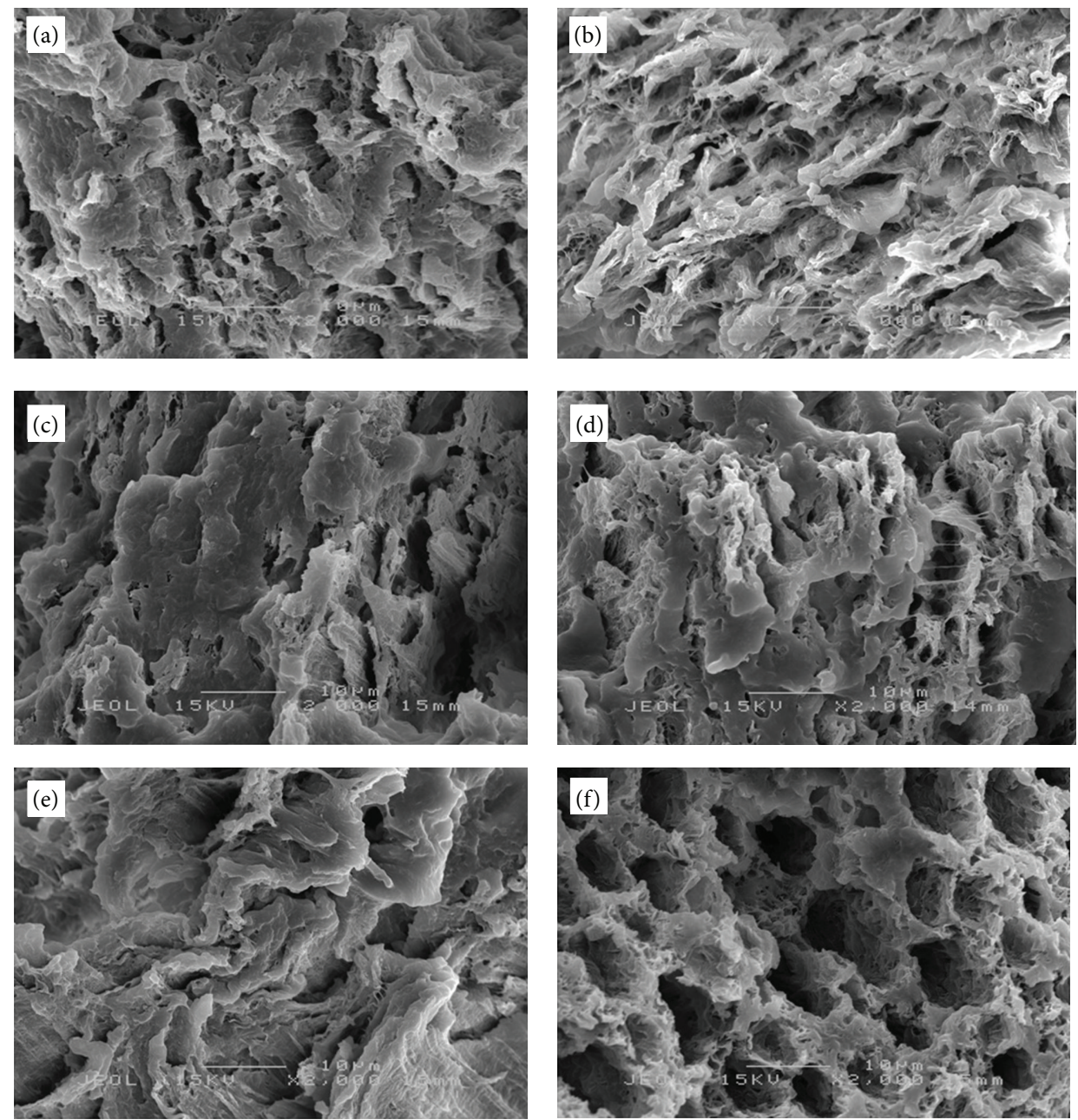

FIGURE 9: Scanning electron micrographs of (a) 80PHB/20PCL blend and PHB/PCL/stearate Mg-Al LDH nanocomposites with (b) 0.25, (c) 0.5 , (d) 1 , (e) 1.5 , and (f) $2 \mathrm{wt} \%$ stearate $\mathrm{Mg}-\mathrm{Al} \mathrm{LDH}$ content at 2000x magnification.

\section{Acknowledgments}

Financial support from Kementerian Pengajian Tinggi, Malaysia, through MyBrain15 and Graduate Research Fellowship, Universiti Putra Malaysia, is gratefully acknowledged.

\section{References}

[1] M. D. Sanchez-Garcia, E. Gimenez, and J. M. Lagaron, "Morphology and barrier properties of solvent cast composites of thermoplastic biopolymers and purified cellulose fibers," Carbohydrate Polymers, vol. 71, no. 2, pp. 235-244, 2008.

[2] M. A. Abdelwahab, A. Flynn, B. S. Chiou, S. Imam, and W. Orts, "Thermal, mechanical and morphological characterization of plasticized PLA-PHB blends," Polymer Degradation and Stability, vol. 97, no. 9, pp. 1822-1828, 2012.

[3] M. Avella, J. J. De Vlieger, M. E. Errico, S. Fischer, P. Vacca, and M. G. Volpe, "Biodegradable starch/clay nanocomposite films for food packaging applications," Food Chemistry, vol. 93, no. 3, pp. 467-474, 2005.

[4] D. Z. Bucci, L. B. B. Tavares, and I. Sell, "PHB packaging for the storage of food products," Polymer Testing, vol. 24, no. 5, pp. 564-571, 2005.
[5] C. S. Wu, "Assessing biodegradability and mechanical, thermal, and morphological properties of an acrylic acid-modified poly(3-hydroxybutyric acid)/wood flours biocomposite," Journal of Applied Polymer Science, vol. 102, no. 4, pp. 3565-3574, 2006.

[6] Y. S. Chun and W. N. Kim, "Thermal properties of poly (hydroxybutyrate-co-hydroxyvalerate) and poly( $\varepsilon$-caprolactone) blends," Polymer, vol. 41, no. 6, pp. 2305-2308, 2000.

[7] Y. S. Chun, J. Park, J. B. Sun, and W. N. Kim, "Blends of polycarbonate and poly( $\varepsilon$-caprolactone $)$ and the determination of the polymer-polymer interaction parameter of the two polymers," Journal of Polymer Science B, vol. 38, no. 15, pp. 20722076, 2000.

[8] D. Lovera, L. Márquez, V. Balsamo, A. Taddei, C. Castelli, and A. J. Müller, "Crystallization, morphology, and enzymatic degradation of polyhydroxybutyrate/ polycaprolactone (PHB/PCL) blends," Macromolecular Chemistry and Physics, vol. 208, no. 9, pp. 924-937, 2007.

[9] C. Hinüber, L. Häussler, R. Vogel, H. Brünig, G. Heinrich, and C. Werner, "Hollow fibers made from a poly(3-hydroxybutyrate)/poly-e-caprolactone blend," Express Polymer Letters, vol. 5, no. 7, pp. 643-652, 2011. 
[10] M. B. Ahmad, K. Shameli, W. M. Z. W. Yunus, N. A. Ibrahim, and M. Darroudi, "Synthesis and characterization of silver/ clay/starch bionanocomposites by green method," Australian Journal of Basic and Applied Sciences, vol. 4, no. 7, pp. 2158-2165, 2010.

[11] M. B. Ahmad, K. Shameli, M. Darroudi, W. M. Z. W. Yunus, and N. A. Ibrahim, "Synthesis and characterization of silver/clay nanocomposites by chemical reduction method," The American Journal of Applied Sciences, vol. 6, no. 11, pp. 1909-1914, 2009.

[12] M. B. Ahmad, M. Y. Tay, K. Shameli, M. Z. Hussein, and J. J. Lim, "Green synthesis and characterization of silver/chitosan/polyethylene glycol nanocomposites without any reducing agent," International Journal of Molecular Sciences, vol. 12, no. 8, pp. 4872-4884, 2011.

[13] K. Shameli, M. B. Ahmad, S. D. Jazayeri et al., "Investigation of antibacterial properties silver nanoparticles prepared via green method," Chemistry Central Journal, vol. 6, no. 1, pp. 1-10, 2012.

[14] K. Shameli, M. B. Ahmad, E. A. Jaffar Al-Mulla et al., "Green biosynthesis of silver nanoparticles using Callicarpa maingayi stem bark extraction," Molecules, vol. 17, no. 7, pp. 8506-8517, 2012.

[15] M. B. Ahmad, J. J. Lim, K. Shameli, N. A. Ibrahim, and M. Y. Tay, "Synthesis of silver nanoparticles in chitosan, gelatin and chitosan/gelatin bionanocomposites by a chemical reducing agent and their characterization," Molecules, vol. 16, no. 9, pp. 7237-7248, 2011.

[16] K. Shameli, M. B. Ahmad, S. D. Jazayeri et al., "Synthesis and characterization of polyethylene glycol mediated silver nanoparticles by the green method," International Journal of Molecular Sciences, vol. 13, no. 6, pp. 6639-6650, 2012.

[17] K. Shameli, M. B. Ahmad, A. Zamanian et al., "Green biosynthesis of silver nanoparticles using Curcuma longa tuber powder," International Journal of Nanomedicine, vol. 7, pp. 5603-5610, 2012.

[18] M. B. Ahmad, K. Shameli, W. M. Z. W. Yunus, N. A. Ibrahim, A. A. Hamid, and M. Zargar, "Antibacterial activity of silver/clay/chitosan bionanocomposites," Research Journal of Biological Sciences, vol. 4, no. 11, pp. 1156-1161, 2009.

[19] M. B. Ahmad, J. J. Lim, K. Shameli, N. A. Ibrahim, M. Y. Tay, and B. W. Chieng, "Antibacterial activity of silver bionanocomposites synthesized by chemical reduction route," Chemistry Central Journal, vol. 6, no. 1, pp. 1-9, 2012.

[20] K. Shameli, M. B. Ahmad, W. M. Z. W. Yunus, N. A. Ibrahim, M. Jokar, and M. Darroudi, "Synthesis and characterization of silver/polylactide nanocomposites," World Academy of Science, Engineering and Technology, vol. 64, pp. 28-32, 2010.

[21] M. Eili, K. Shameli, N. A. Ibrahim, and W. M. Z. W. Yunus, "Degradability enhancement of poly(lactic acid) by stearate$\mathrm{Zn}_{3} \mathrm{Al} \mathrm{LDH}$ nanolayers," International Journal of Molecular Sciences, vol. 13, no. 7938, 7951 pages, 2012.

[22] M. Zhang, P. Ding, L. C. Du, and B. J. Qu, "Structural characterization and related properties of EVA/ZnAl-LDH nanocomposites prepared by melt and solution intercalation," Materials Chemistry and Physics, vol. 109, no. 2-3, pp. 206-211, 2008.

[23] F. R. Costa, B. K. Satapathy, U. Wagenknecht, R. Weidisch, and G. Heinrich, "Morphology and fracture behaviour of polyethylene/Mg-Al layered double hydroxide (LDH) nanocomposites," European Polymer Journal, vol. 42, no. 9, pp. 21402152, 2006.
[24] S. R. Lee, H. M. Park, H. Lim et al., "Microstructure, tensile properties, and biodegradability of aliphatic polyester/clay nanocomposites," Polymer, vol. 43, no. 8, pp. 2495-2500, 2002.

[25] H. F. Naguib, M. S. Abdel Aziz, S. M. Sherif, and G. R. Saad, "Thermal properties of biodegradable poly(PHB/PCLPEG-PCL) urethanes nanocomposites using clay/poly( $\varepsilon$-caprolactone) nanohybrid based masterbatch," Applied Clay Science, vol. 57, pp. 55-63, 2012.

[26] Y. Kameshima, H. Yoshizaki, A. Nakajima, and K. Okada, "Preparation of sodium oleate/layered double hydroxide composites with acid-resistant properties," Journal of Colloid and Interface Science, vol. 298, no. 2, pp. 624-628, 2006.

[27] Y. Q. Shi, F. Chen, J. T. Yang, and M. Q. Zhong, "Crystalline behaviors and thermal stabilities of layered double hydroxide reinforced polypropylene nanocomposites," Applied Clay Science, vol. 50, pp. 87-91, 2010.

[28] H. M. Park, W. K. Lee, C. Y. Park, W. J. Cho, and C. S. Ha, "Environmentally friendly polymer hybrids-part I: mechanical, thermal, and barrier properties of thermoplastic starch/clay nanocomposites," Journal of Materials Science, vol. 38, no. 5, pp. 909-915, 2003.

[29] Y. Y. Then, N. A. Ibrahim, and W. M. Z. W. Yunus, "Enhancement of tensile strength and flexibility of polycaprolactone/tapioca starch blends by octadecylamine modified clay," Journal of Polymers and the Environment, vol. 19, no. 2, pp. 535539, 2011.

[30] S. Pradhan, F. R. Costa, U. Wagenknecht, D. Jehnichen, A. K. Bhowmick, and G. Heinrich, "Elastomer/LDH nanocomposites: synthesis and studies on nanoparticle dispersion, mechanical properties and interfacial adhesion," European Polymer Journal, vol. 44, no. 10, pp. 3122-3132, 2008.

[31] C. Manzi-Nshuti, P. Songtipya, E. Manias, M. M. JimenezGasco, J. M. Hossenlopp, and C. A. Wilkie, "Polymer nanocomposites using zinc aluminum and magnesium aluminum oleate layered double hydroxides: effects of $\mathrm{LDH}$ divalent metals on dispersion, thermal, mechanical and fire performance in various polymers," Polymer, vol. 50, no. 15, pp. 3564-3574, 2009.

[32] A. Okada and A. Usuki, "Twenty years of polymer-clay nanocomposites," Macromolecular Materials and Engineering, vol. 291, pp. 1449-1476, 2006.

[33] D. M. Lincoln, R. A. Vaia, and R. Krishnamoorti, "Isothermal crystallization of nylon-6/montmorillonite nanocomposites," Macromolecules, vol. 37, no. 12, pp. 4554-4561, 2004.

[34] F. R. Costa, A. Leuteritz, U. Wagenknecht et al., "Alkyl sulfonate modified LDH: effect of alkyl chain length on intercalation behavior, particle morphology and thermal stability," Applied Clay Science, vol. 44, no. 1-2, pp. 7-14, 2009.

[35] M. D. Sanchez-Garcia, E. Gimenez, and J. M. Lagaron, "Development and characterization of novel nanobiocomposites of bacterial poly(3-hydroxybutirate), layered silicates and poly( $\varepsilon$ caprolactone)," Journal of Applied Polymer Science, vol. 108, no. 5, pp. 2787-2801, 2008.

[36] Kusmono, M. W. Wildan, and Z. A. M. Ishak, "Preparation and properties of clay-reinforced epoxy nanocomposites," International Journal of Polymer Science, vol. 2013, Article ID 690675, 7 pages, 2013.

[37] Y. Ding, Z. Gui, J. Zhu, Y. Hu, and Z. Wang, "Exfoliated poly(methyl methacrylate)/MgFe-layered double hydroxide nanocomposites with small inorganic loading and enhanced properties," Materials Research Bulletin, vol. 43, no. 12, pp. 32123220, 2008. 
[38] J. Liu, G. Chen, and J. Yang, "Preparation and characterization of poly(vinyl chloride)/layered double hydroxide nanocomposites with enhanced thermal stability," Polymer, vol. 49, no. 18, pp. 3923-3927, 2008.

[39] H. B. Hsueh and C. Y. Chen, "Preparation and properties of LDHs/polyimide nanocomposites," Polymer, vol. 44, no. 4, pp. 1151-1161, 2003.

[40] J. Sharif, W. M. Z. W. Yunus, K. Z. H. M. Dahlan, and M. H. Ahmad, "Preparation and properties of radiation crosslinked natural rubber/clay nanocomposites," Polymer Testing, vol. 24, no. 2, pp. 211-217, 2005.

[41] H. Essawy and D. El-Nashar, "The use of montmorillonite as a reinforcing and compatibilizing filler for NBR/SBR rubber blend," Polymer Testing, vol. 23, no. 7, pp. 803-807, 2004.

[42] J. S. Shelley, P. T. Mather, and K. L. DeVries, "Reinforcement and environmental degradation of nylon-6/clay nanocomposites," Polymer, vol. 42, no. 13, pp. 5849-5858, 2001.

[43] A. Pozsgay, T. Frater, L. Szazdi, P. Muller, I. Sajo, and B. Pukanszky, "Gallery structure and exfoliation montmorillonite: effect on composite properties," European Polymer Journal, vol. 40, pp. 27-36, 2004.

[44] N. Cao, X. Yang, and Y. Fu, "Effects of various plasticizers on mechanical and water vapor barrier properties of gelatin films," Food Hydrocolloids, vol. 23, no. 3, pp. 729-735, 2009.

[45] N. Hasegawa, M. Kawasumi, M. Kato, A. Usuki, and A. Okada, "Preparation and mechanical properties of polypropyleneclay hybrids using a maleic anhydride-modified polypropylene oligomer," Journal of Applied Polymer Science, vol. 67, no. 1, pp. 87-92, 1998.

[46] L. Averous, L. Moro, P. Dole, and C. Fringant, "Properties of thermoplastic blends: starch-polycaprolactone," Polymer, vol. 41, no. 11, pp. 4157-4167, 2000. 

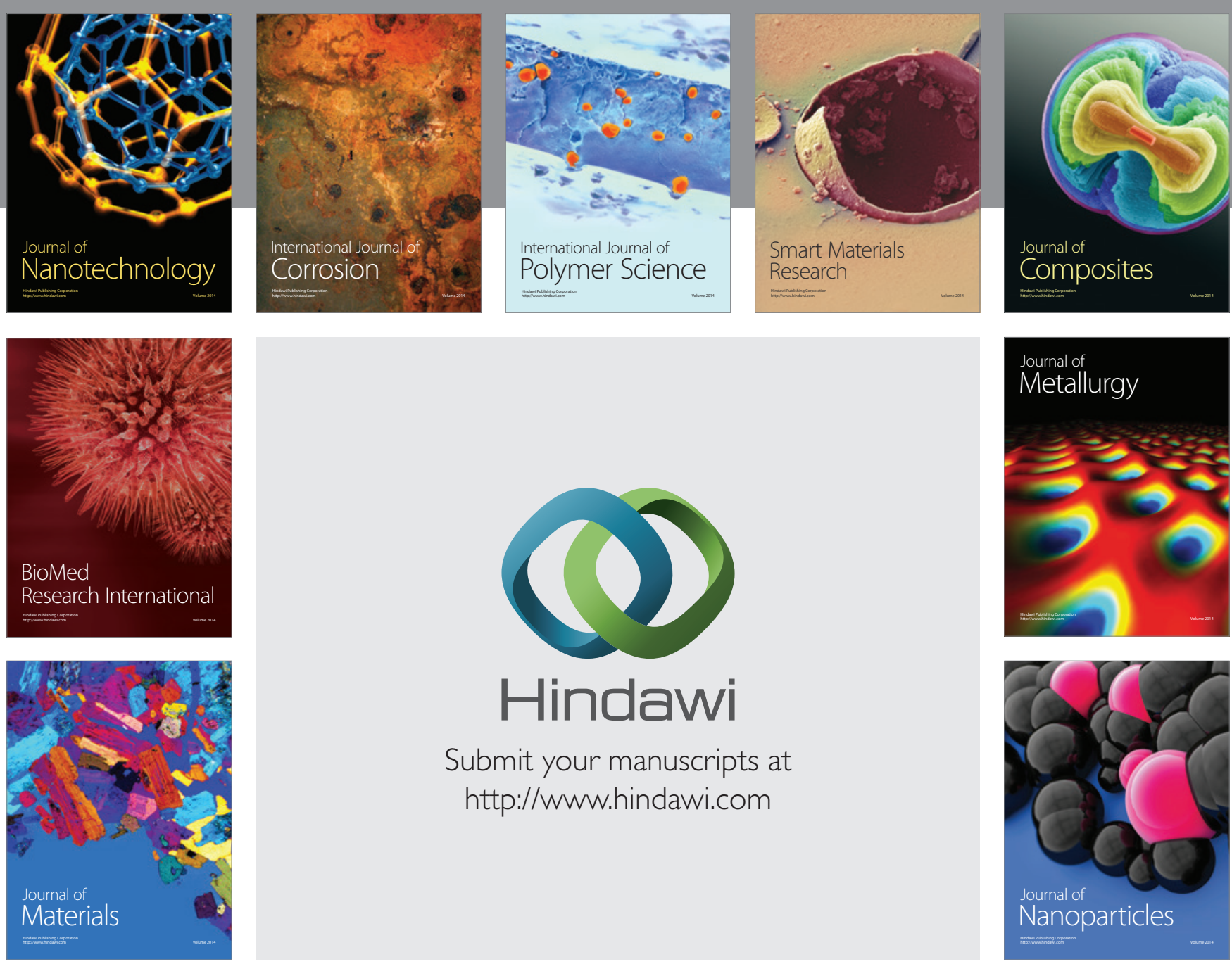

Submit your manuscripts at http://www.hindawi.com
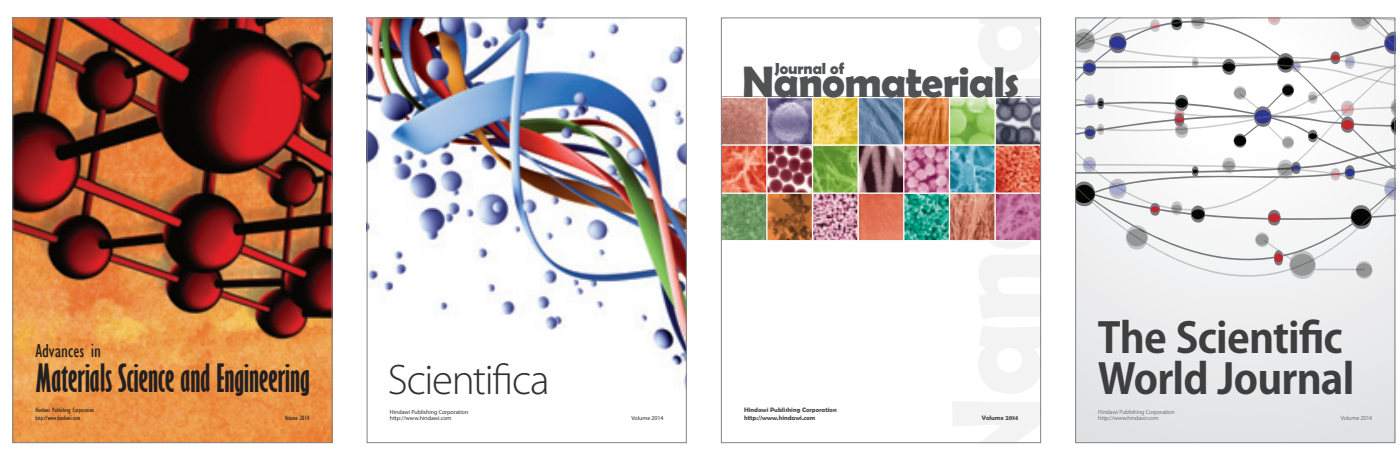

\section{The Scientific World Journal}
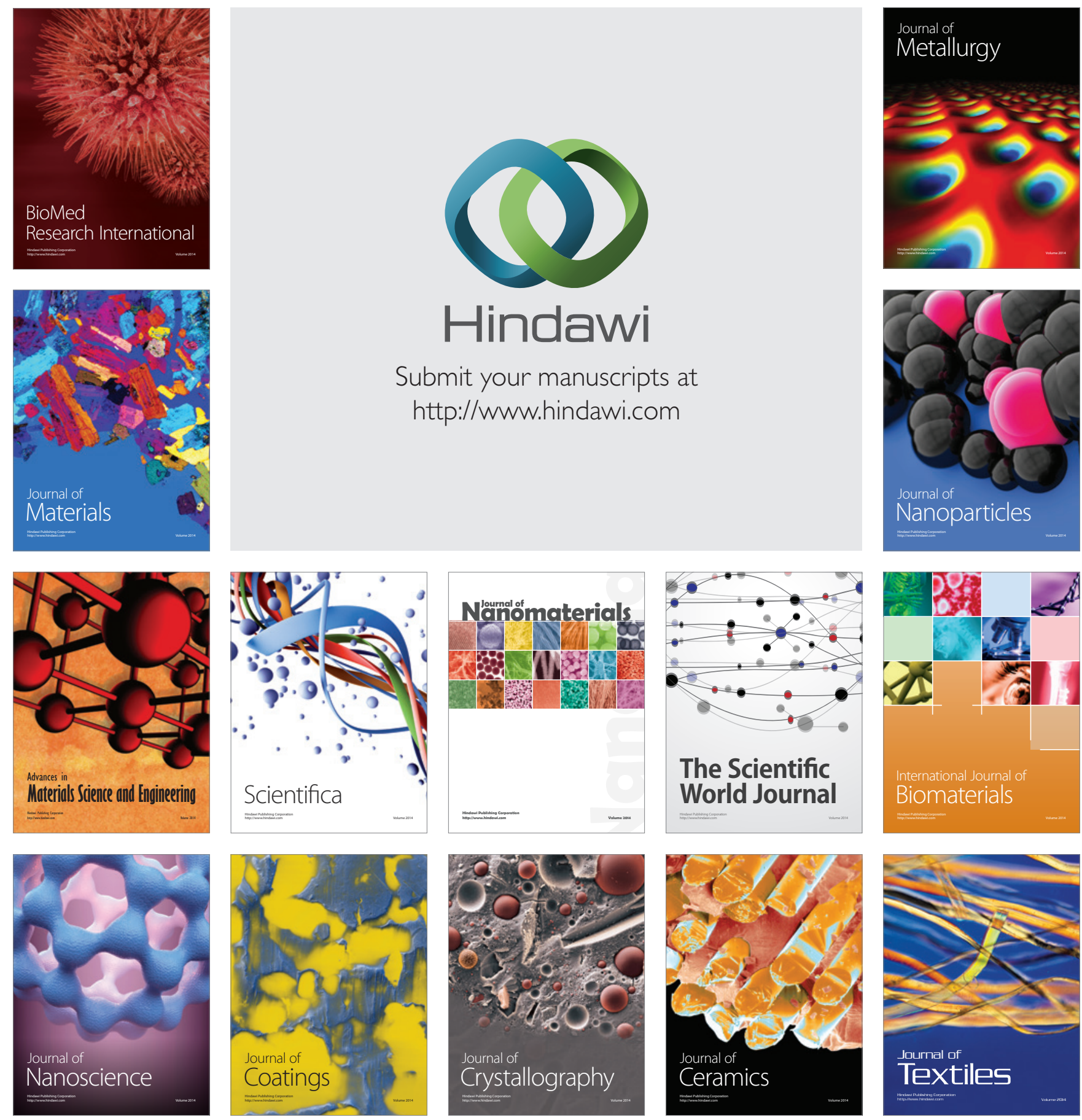